\title{
EFFECT OF NATIONAL HOME GROWING SCHOOL FEEDING PROGRAM (NHGSFP) ON THE NUTRITIONAL STATUS OF CHILDREN OF RURAL HOUSEHOLDS IN OSUN STATE, NIGERIA
}

\author{
${ }^{1}$ Adebisi O.A, ${ }^{2}$ Adebisi L.O*, ${ }^{3}$ Jonathan A, ${ }^{4}$ Ajani 0.0 and ${ }^{5}$ Asogwa U. G \\ ${ }^{1}$ Department of Agricultural Economics and Farm Management, University of Ilorin, PMB 1515, \\ Ilorin, Nigeria. \\ ${ }^{2}$ General Management Division, Agricultural Development Management Department, \\ Agricultural and Rural Management Training Institute (ARMTI) Ilorin, Nigeria \\ ${ }^{3}$ Department of Agricultural Education, FCT College of Education, Zuba-Abuja \\ ${ }^{4}$ Agricultural Project Management Division, Agricultural Development Management \\ Department, Agricultural and Rural Management Training Institute (ARMTI) Ilorin, Nigeria \\ ${ }^{5}$ Reseach Division, Training Technology Department, Agricultural and Rural Management \\ Training Institute (ARMTI) Ilorin, Nigeria \\ *Corresponding author e-mail: tobadebisi@gmail.com
}

\begin{abstract}
The "National Home Growing School Feeding Program" by Nigeria government was designed to overcome malnutrition disorders through regular school-feeding to improve the nutrition status and the education abilities of school children. Hence, this study focused on assessing the effect of 'national home growing school feeding program' on the nutritional status of children of rural households in Osun State, Nigeria. Primary data was used for the study. Two stage random sampling was used for the study, the first stage which was the random selection of four (4) rural communities from each of the three (3) Agro-ecological zones present in the state and the second stage was the random sampling of 10 households from each of the selected communities, comprising of households whose children are beneficiaries and not beneficiaries of the program. A total of 120 households were used for the study. A structured questionnaire was used for the purpose of extracting needed information from the respondents. The data collected was analyzed using Descriptive Statistics, Anthropometry, Logistics Regression Model and Chi-square Analysis. Result of analysis revealed that nutritional status of children in the study area is significantly influenced by child's sex, child's age, mother's education, national home growing school feeding program, access to clean water, access to sanitation facilities and household income. The effect of national home growing school feeding program on the nutritional status of the children was statistically significant (chi-square $=37.263, p<0.000$ ) which means the program has positive effect on the nutritional status of children in the study area. The study therefore recommended that government should ensure the sustenance of National Home Growing School Feeding Program especially in the rural areas of the country. Education of the rural women folks should be taken importantly by governments and NGOs as they are the one directly taking care of children wellbeing. Government, NGOs and Community groups should Journal of the Faculty of Agriculture and Veterinary Medicine, Imo State University Owerri website: www ajol.info
\end{abstract}


also provide the basic amenities like portable water supply and sanitation facilities in the rural areas so as to curb the incidence of diseases and malnutrition.

Keywords: National Home Grown School Feeding Program, Nutritional Status, Health, Malnutrition

https://dx.doi.org/10.4314/jafs.v17i2.12

\section{INTRODUCTION}

Agriculture is a core medium for driving growth and development in developing countries. Despite this, about 925 million people worldwide still suffer from chronic hunger and malnutrition, out of which 235 million are from sub-Sahara Africa (Food and Agriculture Organization, 2013). While one of the goals of the United Nations Goal 2 is to end hunger, achieve food security, improved nutrition and promote sustainable agriculture" by 2030. This will in turn enhance sustainable development (FAO, 2010; FAO, 2013).

Malnutrition, which is often referred to as "hidden hunger", is defined by the World Food Programme (2005) as "a state in which the physical function of an individual is impaired to the point where he or she can no longer maintain adequate bodily performance processes such as growth, pregnancy and lactation as a result of poor or low quality diet". It results in disability, morbidity, and mortality, especially among infants and young children.

Malnutrition often begins at conception, and child malnutrition is linked to poverty, low levels of education, and poor access to health services, including reproductive health and family planning (International Food Policy Research Institute, 2014). It commonly affects all groups in a community, but the most vulnerable are infants, young children and pregnant women because of their high nutritional requirements for growth and development (World Health Organization, 2005).

Malnutrition is common in developing countries like Nigeria (DHS, 2013), which may be as a result of the following: Low income resulting in low purchasing power for adequate food, lack of access to nutritious foods, lack of awareness about proper nutrition and importance, poor quality of food due to contamination with agrochemicals (pesticides), bio-chemicals (e.g. aflatoxins), or pests and diseases. Nigeria was ranked $40^{\text {th }}$ among 79 countries using the Global Hunger Index (GHI), together with her rising food prices, malnutrition and deaths as a result of wide-spread poverty is an indication of the prevalence of food insecurity and under nutrition in the country.

Several programmes were introduced in the past to tackle this problem. The programmes include National Agricultural Development Fund, NADF (2002); National Special Program on Food Security, NSPFS (2002); National Food Crisis Response program [NFCRP], Food Security Thematic Group [FSTG] in 2009; Scaling-Up Nutrition (SUN) Movement in 2011, Global Nutrition for Growth Compact in 2013, Working to Improve Nutrition in Northern Nigeria (WINNN) in 2011 and Agriculture Promotion Policy (APP) (Okolo, 2009). Yet, the goal of food security has not been achieved especially among youths who are vulnerable in the rural Journal of the Faculty of Agriculture and Veterinary Medicine, Imo State University Owerri website: www ajol.info 
communities. This is because of several challenges faced at the implementation, and execution stages of these programs.

As a result, the National Home Growing Feeding Program was launched in 2016 to solve the problem of malnutrition especially in the rural communities. The program is basically a provision of food to school-children (Akanbi and Alayande, 2017) in order to reduce micronutrient malnutrition while supporting education, health, and agriculture community development (WFP, 2017). The programme was launched in twelve (12) States in the six geopolitical zones; Bauchi, Edo, Enugu, Federal Capital Territory [FCT], Imo, Kano, Kogi, Nassarawa, Niger, Ogun, Yobe and Osun States. So far, there has not being a study that assess the activities of this program especially on the rural community.

Therefore, the study seeks to assess the effect of the programme on the nutritional status of children of rural households in Osun State, Nigeria. The objectives are to

- describe the demographic characteristics of children and socio-economic characteristics of rural household heads;

- examine factors influencing the nutritional status of primary school children in the study area;

- examine the effect of the national home growing school feeding programme on the nutritional status of primary school children of rural households in the study area;

\section{MATERIALS AND METHOD}

\section{Study Area}

The study was carried out in Osun state. Osun state is an inland State in south-western Nigeria. Its capital is Osogbo. It is bounded in the north by Kwara State, in the east partly by Ekiti State and partly by Ondo State, in the south by Ogun State and in the west by Oyo State. The state consists of thirty (30) Local Government Areas and divided into three Agricultural zones. The State lies on latitude $8^{\circ}$ to the North and longitude $6^{\circ}$ to the South, then it is marked by longitude $4^{\circ}$ to the west and longitude $5^{\circ}$ to the east (OSSADEP, 2004). It exhibits the typical tropical climate with prominent wet and dry seasons with fertile soil which encourages the production of crops and livestock. The rainy season generally occur between April and October while the dry season occurs between November and March. Osun State has tropical humid climate. The mean annual temperature for Osun State varies between 21.1 and $31.1^{\circ} \mathrm{C}$. Annual rainfall is within the range of $1,000 \mathrm{~mm}$ in the derived savannah agro-ecology to $1,200 \mathrm{~mm}$ in the rainforest belt (Osun State Ministry of Agriculture, 2014). The dominant occupation and economic activities of the people centres around farming, agro allied productions, trading, and artisanship (OSSADEP, 2004). The state comprises of 1,430 primary schools. The enrolment of primary school pupils is 331,509 and pupils' intake is 61,500 per year in Osun State (Universal Basic Education Commission, 2010).

\section{Journal of the Faculty of Agriculture and Veterinary Medicine, Imo State University Owerri} website: www ajol.info 
Journal of Agriculture and Food Sciences

Volume 17 Number 2, October 2019 pp 148 - 163

Asogwa U.G.

\section{Data and Sampling Techniques}

Two stage random sampling was used for the study. The first stage was the selection of four (4) rural communities from each of the three (3) ADPs present in the state. The second stage was the random sampling of 10 households from each of the selected communities, comprising of households whose children are benefitting and not benefitting from national school feeding. The last stage was random selection of a primary school pulpil from each household. A total of 120 households were used for the study. The data for this study was collected using a structured questionnaire to solicit response on the demographic characteristics of children, socio-economic characteristics of rural households in the study area. Also, information was collected on the sources of livelihood, nutritional status of children in Osun State, Nigeria.

\section{Analytical Techniques}

\section{Descriptive Analysis}

Descriptive statistics comprising the use of measures of central tendency and dispersion mean, percentages, frequency and tabulation was used to capture the socio-economic and demographic characteristics of the respondents.

\section{Nutritional Status}

Nutritional assessment was done using anthropometry. Children were weighed and measured according to standard procedures described by WHO on Anthropometry (Myatt, Khara, \& Collins, 2006; International Institute of Population Sciences and ORCMacro, 2000).

All measurements were taken with the children wearing light clothing and without shoes. Each child was weighed using a calibrated standardized digital weighing scale, with the accuracy of the scale to the nearest $0.5 \mathrm{~kg}$. The weight was recorded twice and the average value used in the analysis. The scale was set to zero point before each use and checked for accuracy with standard weights whenever the scale was moved from place to place. Heights were measured with a wooden stadiometer placed on a flat surface measured to the nearest $0.1 \mathrm{~cm}$. Two measurements were taken and the average value was obtained. The mid arm circumference was measure with a measuring tape on two consecutive times. The sensitivity is $0.1 \mathrm{~cm}$. BMI was calculated using the formula:

$$
B M I=\frac{\text { Weight }(\mathrm{Kg})}{\operatorname{Height}\left(M^{2}\right)}
$$

In line with the national guidelines for nutrition surveys, malnutrition was the indicator used to measure the nutritional status of children.

Weight-for-age, Height-for-age, and BMI-for-age were derived from the new WHO standard. Computed $\mathrm{Z}$ scores for $\mathrm{BMI}$ for age, weight for age and height for age were then used to assess underweight, wasting, and stunting using the recently published WHO reference standards. Normal height was defined as height for age which is between -2 and $+2 \mathrm{Z}$ score while normal Journal of the Faculty of Agriculture and Veterinary Medicine, Imo State University Owerri website: www ajol.info 
weight was defined as weight for age between -2 and $+2 \mathrm{Z}$ score. Stunting and underweight were defined as height and weight for age less than $-2 \mathrm{Z}$ score respectively. Wasting was defined as BMI for age less than $-2 \mathrm{Z}$ score while obesity was defined as BMI greater than $+2 \mathrm{Z}$ score. Overweight was defined as BMI for age between +1 and $+2 \mathrm{Z}$ score.

\section{Logistic Regression Model}

The logistic regression model was used to examine the factors influencing the nutritional status of children of rural households in the study area.

The Logit regression model is specified as

$$
P_{1}=E\left(y=1 / X_{i}\right)=\beta_{0}+{ }_{i} X_{i}
$$

Where $\mathrm{X}_{\mathrm{I}}$ represents explanatory variables included in the model, $\mathrm{Y}=$ Nutritional Status of children which is either 1 if Malnourished or 0 Otherwise.

$$
P_{1}=E\left(y=1 / X_{i}\right)=\frac{1}{\left|1+e-\left(\beta_{0}+\beta_{1} X_{1}\right)\right|}
$$

Therefore,

$$
P_{1}=\frac{1}{1+e^{-z_{i}}}=\frac{e^{z_{i}}}{1+\mathrm{E}_{z I}}
$$

This is (cumulative) logistic distribution function. Where $\mathrm{Z}_{\mathrm{I}} \mathrm{Zi}$ ranges from $\mathrm{x} \mathrm{P}_{\mathrm{i}}$ ranges between $\mathrm{O}$ and $1, \mathrm{P}_{\mathrm{i}} \mathrm{P}$ is non- linearly related to $\mathrm{Zi}$ (i.e. $\mathrm{Xi}$ ).

$\mathrm{Pi}=$ Probability of an individual choosing an alternative $\mathrm{i}$

$$
\beta_{0}=\text { Constant }
$$

$\mathrm{B}_{1} \ldots \mathrm{B}_{10}=$ Coefficient of the explanatory variable $\mathrm{X}_{1} \ldots \ldots . \mathrm{X}_{10}$

$\mathrm{Y} y=f\left(\mathrm{X}_{1}, \mathrm{X}_{2}, \mathrm{X}_{3}, \mathrm{X}_{4}, \mathrm{X}_{5}, \mathrm{X}_{6}, \mathrm{X}_{7}, \ldots \ldots \ldots \mathrm{X}_{13}, \varepsilon_{\mathrm{i}}\right)$

(5) based on the household production framework of Becker (1965) and Strauss and Thomas (1995).

$y=$ Nutritional Status of Children (dummy Variable; $1=$ Malnourished, $0=$ otherwise)

$\mathrm{X}_{1}$ - Child's Sex (male or female)

$\mathrm{X}_{2}$ - Child's Age (years)

$\mathrm{X}_{3}$ - Household size (number)

Journal of the Faculty of Agriculture and Veterinary Medicine, Imo State University Owerri website: www ajol.info 
Journal of Agriculture and Food Sciences

Volume 17 Number 2, October 2019 pp $148-163$

Asogwa U.G.

$\mathrm{X}_{4}$ - Mother's Education (years of schooling)

$\mathrm{X}_{5}$ - School Feeding Program (dummy)

$\mathrm{X}_{6}$ - Mother's Access to Resources (dummy)

$\mathrm{X}_{7-}$ Access to clean water (dummy)

$\mathrm{X}_{8}-$ Access to sanitation facilities (dummy)

$\mathrm{X}_{9}-$ Household Income (Naira)

$\alpha$ - Intercept

$\varepsilon_{\mathrm{i}}-$ Error term, assumed to be uniformly distributed.

Chi-square Analysis

This was used to determine the association and effect between nutritional status of children and national school feeding program (which are categorical variables) in the study area.

\section{RESULTS AND DISCUSSION}

\section{Demographic Characteristics of Children and Socio-Economic Characteristics of Household}

Table 1 shows the summary of child variables and socio-economic characteristics of household. As given in Table 1, results show that of the 120 children in the sample households, $61 \%$ were female, while $39 \%$ were male. The mean age of children was $7.5 y$ years. About $41.7 \%$ of the children were of birth intervals equal or less than two years. $37.5 \%$ of the children sampled were stunted which implies they are suffering from chronic malnutrition. This occurrence of stunting is conversely close to the national average of $38 \%$ recorded during the 2003 Nigeria Demographic and Health Survey (Ajieroh, 2010) but lower when compared with the 42\% recorded during the Nigeria Food Consumption and Nutrition Survey in 2004 (Ajieroh, 2010). $22.5 \%$ of the children were underweight, while $17.5 \%$ are wasted. Also, out of the sampled households, $44 \%$ of the children benefitted from the school feeding program. Eighty-three percent of the household were headed by males and most $(93 \%)$ of them were married in the study area. The modal age range is $31-45$ years and the average age of the household heads is 42.5 years. This is an indication that majority of the household heads in the study area are in their middle age and still active. About $60 \%$ of the household heads have at least primary education. The modal household's size is 3-6 members and the average household size is 6 persons per household. The average farming experience of the farmers is 19.58 years which indicates that the farmers in the study are have vast experience in farming. The average farm size of households in the study area was 2.5 ha with the modal farm size being $(<5.0)$ ha. This suggests that majority of households in the study area are small scale farmers with farm size less than 5ha. The results also show that the total household annual income from all income sources is $\$ 42,062$ naira per capita. Though this is lower when compared with the national average of \$45, 250 in Nigeria, Journal of the Faculty of Agriculture and Veterinary Medicine, Imo State University Owerri website: www ajol.info 
nevertheless a moderate amount for rural households in of Nigeria (NBS, 2006). The educational level of the mother indicates that majority of the mothers had received at least primary level education (63.3\%). The level of education could have effect on child care and nutrition as many of the mothers may lack the basic skills and knowledge to look after their children by offering nutritious feeding. Results also indicate that about $35 \%$ of mothers in the study area have access to resources while majority (65\%) doesn't have access and control over resources, which could prevent mothers from being able to fully cater and provide the necessary nutrition for their children and household wellbeing. Access to clean water and sanitation facilities which are pointers of healthy environment can improve child health and nutrition. This study results show that about $41 \%$ of the households have access to clean water, while $27.5 \%$ have sanitary facilities in their house.

\section{Factors Influencing Nutritional Status of Children in the Study Area}

The result as shown in Table 2 reveals that nutritional status of children in the study area is significantly affected by child's sex, child's age, mother's education, school feeding program, access to clean water, access to sanitation facilities and household income.

The coefficient of child's sex was positive and significant at $10 \%$, which implies that male children are more likely to be malnourished when compared with their female counterpart. This is in consonance with the result of the study carried out by Babatunde et al., 2011.

The coefficient of child's age was also found to be positive and significant at $1 \%$ implying that older children are more likely to be malnourished. This result is in agreement with other studies like Sarmistha 1999; Yimer, 2000; and Kabubo et al 2006.

The coefficient of mother's education was negative and significant at $1 \%$ which implies that improving mother's education will lessen the level of child malnutrition. This result is similar with the findings of Webb and Block (2004), which stated the importance of investing in education in enhancing children nutritional status. Educated mothers are well informed about the nutritional needs of their children and they usually give improved health care as a result of their knowledge.

The coefficient of school feeding program was negative and significant at $1 \%$, implying that an increase in children benefitting from the school feeding program the likelihood of them not being malnourished.

The coefficient of access to clean water and access to sanitation facilities were negative and significant at $5 \%$ and $1 \%$ respectively. This implies that having sanitary facilities in the household has a significant negative effect on the probability of being malnourished. This is not alarming because better sanitary facilities lower the risk of being exposed to infectious diseases and malnutrition. Also, access to clean water reduces the occurrence of malnutrition among the children sampled. Access to clean water and sanitation facilities are health variables that have 
been revealed in literatures to contribute to improved nutritional status of children (Armar et al., 2000).

Household income was shown to be significant at 5\% and had a negative relationship with child's nutritional status. This implies that if household income is improved upon, the calorie intake of the household will also improve which will in turn produce a well-nourished child (Smith and Haddad, 1999).

The coefficient of determination $\left(\mathrm{R}^{2}\right)$ shows that the explanatory variables explain about $65.41 \%$ of the variations in the factors influencing nutritional status of children leaving about $34.59 \%$ unexplained.

Variables such as household size and mother's access to resources were not significant in explaining the factors influencing the nutritional status of children in the study area.

\section{Effect of National School Feeding Programme on Nutritional Status of Children}

Table 3 shows the result of the effect of National Home Grown School Feeding Programme on the nutritional status of children. The probability of the chi-square test statistic (chi-square = 37.263), $p<0.000$, less than the alpha level of significance of 0.05 . The association between "National School Feeding Program" and "Nutritional Status" was statistically significant. This revealed that National Home Growing Feeding program has positive effect on the nutritional status of children in the study area, which also showed that the activity of the program was beneficial to the children involved. Which is in line with the apriori expectation

Table 4 shows the Phi and Cramer's V which both shows the strength of association. The strength of association between National School Feeding Program and Nutritional Status is moderate (0.316).

\section{CONCLUSION AND RECOMMENDATION}

The study concluded that the National Home Growing School Feeding Program has effect on the nutritional status of children in the study area. All other variables that influenced children nutritional status were child's sex, child's age, mother's education, access to clean water, access to sanitation facilities and household income. However, the study recommends that if the issue of child malnutrition is to be overcome completely:

- The government should ensure the sustenance of National Home Growing School Feeding Program in the rural based areas of the country.

- Education of the rural women should be given more attention by the government as they are the one directly taking care of children. This will improve the quality of food given to their children 


\section{REFERENCES}

Ajieroh, V. (2010). A Quantitative Analysis of Determinants of Child and Maternal Malnutrition in Nigeria. IFPRI Nigeria Strategy Support Program Brief No. 11, 2010.

Akanbi, G.O. \& Alayande, E., (2017). Home grown school feeding and health program in nigeria: an innovative approach to boosting enrolment in public primary schools -a study of Osun State 2002 -2010. The African Symposium: An online journal of the African Educational Research Network.,11(2): 20-28

Armar-Klemesu, M., Ruel, M.T., Maxwell, D.G., Levin, C.E. \& Morris, S.S. (2000). Poor Maternal Schooling is the Main Constraint to Good Childcare Practices in Accra. Journal of Nutrition, 130, 1597-1607.

Babatunde, R.O., Olagunju, F.I., Fakayode, S.B. \& Sola-Ojo, F.E. (2011). Prevalence and Determinants of Malnutrition among Under-five Children of Farming Households in Kwara State, Nigeria. Journal of Agricultural Science, 3(3):173-181

Becker, G. (1965). A Model of the Allocation of Time. Economic Journal. 75, 493-517. http://dx.doi.org/10.2307/2228949

Demographic and Health Survey - DHS (2013). Nigeria Demographic and Health Survey, Factsheet.

Food and Agriculture Organization -FAO, (2013) FAO Discussion Paper on Strengthening the Links between Resilience and Nutrition in Food and Agriculture, Draft. FAO [Link]

FAO, (2010). Global Hunger Declining but Still Unacceptably High: International Hunger Targets Difficult to Reach. Economic and Social Development Department September 2010. Rom e: FAO

Global Hunger Index Report (2012): The Challenge of Hunger: Ensuring Sustainable Food Security under Land, Water and Energy stresses. IFP RI, Concern Worldwide, Welthungerhilfe and Green Scenery: Bonn / Washington, DC / Dublin October 2012

International Food Policy Research Institute. (2014). Global Nutrition Report 2014: Actions and Accountability to Accelerate the World's Progress on Nutrition. Washington, DC.

International Institute of Population Sciences and ORCMacro, (2000). National Family Health Survey India. (NFHS 2) 1998-99: India. Mumbai: I.I.P.S; 2000.

Isaac, O.A., (2009). Ensuring Food and Nutrition Security in Rural Nigeria: An Assessment of the Challenges, Information Needs, and Analytical Capacity. National Strategy Support Program (NSSP) Background Paper No 007, Abuja: IFPRI

Kabubo-Mariara, J., Ndenge, G.K. \& Kirii, D.M. (2006). Determinants of Children's Nutritional Status in Kenya: Evidence from Demographic and Health Surveys. Paper Presented at the 
Centre for the Study of African Economies Conference, University of Oxford, March 1721, 2006.

Maziya-Dixon, B., Akinyele I.O., Oguntona E.B., Nokoe S., Sanusi R.A. \& Harris, E., (2004). Background. Nigeria food consumption and nutrition survey, summary, IITA, Ibadan, Nigeria. Pp. 9.

Myatt, M., Khara, T., \& Collins, S., (2006). A review of methods to detect cases of severely malnourished children in the community for their admission into community-based therapeutic care programs. Food Nutrient Bulletin pg 27. Available on https://www.who.int/nutrition/publications/severemalnutrition/FNB_03795721_A_revie w.pdf?ua=1

NBS. (2006). National Bureau of Statistics, Abuja, Socio-economic Survey of Nigeria.

Nigeria National Population Commission and ICF International, Nigeria Demographic and Health Survey 2013: Preliminary Report, 2013.

Okolo, D., (2009): Regional Study on Agricultural Support, Nigeria's Case. FAO. http://www.fao.org/tc/tca/work05/nigeria.pdf.

Osun State Agriculture. Development Programme (OSSADEP), 2004. Annual report on Fadama programme. Iwo, Osun State.

Osun State Ministry of Agriculture, 2014. "Boosting Agricultural Activities in Osun State" Retrieved from http://www.osundefender.org/?tag

Sarmistha, P. (1999). An Analysis of Childhood Malnutrition in Rural India: Role of Gender, Income and Other Household Characteristics. World Development, 27, 1151-1171. http://dx.doi.org/10.1016/S0305-750X(99)00048-0

Smith, L.C. \& Haddad, L. (1999). Explaining Child Malnutrition in Developing Countries: A Cross-Country Analysis. IFPRI FCND Discussion Paper No. 60, IFPRI, Washington, D.C. USA.

Smith, J., \& Todd, P., (2005). Does Matching Overcome LaLonde's Critique of Non experimental Estimators? Journal of Econometrics, 125(1-2): 305-353.

Strauss J., \& Thomas, D., (1995). Human Resources: Empirical Modeling of Household and Family Decisions. In J. Behrman and T.N. Srinivasan, eds., Handbook of Development Economics, Vol. 3. Amsterdam; North-Holland.

Universal Basic Education Commission (2010): National and Regional Statistics of 2010 Basic Education Profile in Southwest Nigeria.

UNICEF, (2006). Information factsheet.p. 2. 
*Webb P. \& Block, S. (2004). Nutritional Information and Formal Schooling as Inputs to Child Nutrition. Economic Development and Cultural Change, 55, 801-820. Food Programme, (2007). Food and Nutrition Handbook. Rome.

World Food Programme- WFP, (2017). Emergency Food Security Assessment Handbook. http://www.wfp.org/operations/emergency_needs/EFSAsection1.pdf_Food and Nutrition Handbook. Rome.

World Health Organization - WHO, (2005). The World Health Report 2005 - make every mother and child count.

Yimer, G. (2000). Malnutrition among children in southern Ethiopia: Levels and risk factors. Ethiopian Journal of Health Development, 14(3), 283-292.

Yunusa, I., Gumel, A. M., Adegbusi, K., \& Adegbusi, S., (2012). "School Feeding Program in Nigeria: A Vehicle for Nourishment of Pupils." In The African Symposium: An Online Journal of African Educational Research Network 12 (2): 104-110. 
Journal of Agriculture and Food Sciences

Adebisi, O.A., Adebisi L.O., Jonathan A., Ajani O.O. and 159

Volume 17 Number 2, October 2019 pp 148 - 163

Asogwa U.G.

APPENDIXES

Table 1: Children Variables and Socio-Economic Characteristics of Household Demographic Characteristics of Children

\begin{tabular}{lll}
\hline Characteristics & Frequency & Percentage \\
\hline Child's Age (years) & 00 & \\
$<3$ & 31 & 00 \\
$3-6$ & 59 & 25.8 \\
$7-9$ & 30 & 49.2 \\
$>10$ & 120 & 25.0 \\
Total & & 100 \\
Child's Sex & 47 & \\
Male & 73 & 39.2 \\
Female & 120 & 60.8 \\
Total & & 100
\end{tabular}

Birth Interval (years)

$\begin{array}{lll}</=2 & 50 & 41.67 \\ 3-4 & 47 & 39.17 \\ 5-6 & 23 & 19.16 \\ \text { Total } & 120 & 100\end{array}$

Nutritional Status

$18 \quad 15.0$

Stunting

$45 \quad 37.5$

Wasting

$21 \quad 17.5$

Underweight

$27 \quad 22.5$

Overweight

$7 \quad 5.8$

Obesity

$2 \quad 1.7$

Total

120

100

School Feeding Program

\begin{tabular}{lll} 
Yes & 53 & 44.17 \\
No & 67 & 55.83 \\
Total & 120 & 100 \\
\hline
\end{tabular}

Journal of the Faculty of Agriculture and Veterinary Medicine, Imo State University Owerri website: www ajol.info 
Adebisi, O.A., Adebisi L.O., Jonathan A., Ajani O.O. and 160

Journal of Agriculture and Food Sciences Asogwa U.G.

Volume 17 Number 2, October 2019 pp 148 - 163

$\begin{array}{lr}\text { Socio-economic Characteristics of Households } & \text { Fr } \\ \text { Characteristics } & \\ \text { Age of Household Head } & 2 \\ 30 & 74 \\ 31-45 & 4 \\ 46-60 & 12 \\ \text { Total } & 42 \\ \text { Mean Age } & \\ \text { Gender of Household Head } & \end{array}$

$\begin{array}{lrr}\text { Female } & 20 & 16.7 \\ \text { Male } & 100 & 83.3 \\ \text { Total } & 120 & 100.0\end{array}$

Marital Status of Household Head

Single

0.0

Divorced

$8 \quad 6.7$

Married 112

93.3

Total

120

100.0

Educational Level of Household Head

No formal 48

40.0

Primary

51

42.5

Secondary

17

14.2

Tertiary

Total

120

100.0

Household size

$\begin{array}{lrr}<3 & 14 & 11.7 \\ 3-6 & 85 & 70.8 \\ >6 & 21 & 17.5 \\ \text { Total } & 120 & 100.0 \\ \text { Mean } & 6.2 & \\ \text { Farming Experience } & & \\ \leq 10 & 11 & 9.16 \\ 11-20 & 61 & 50.8 \\ 21-30 & 30 & 25.0 \\ >30 & 18 & 15.0 \\ \text { Total } & 120 & 100.0 \\ \text { Mean } & 19.6 & \end{array}$

Journal of the Faculty of Agriculture and Veterinary Medicine, Imo State University Owerri website: www ajol.info 
Journal of Agriculture and Food Sciences

Adebisi, O.A., Adebisi L.O., Jonathan A., Ajani O.O. and 161 Volume 17 Number 2, October 2019 pp $148-16.3$

Asogwa U.G.

\begin{tabular}{|c|c|c|}
\hline \multicolumn{3}{|c|}{ Farm Size (hectares) } \\
\hline$>5$ & 88 & 73.3 \\
\hline $5-10$ & 32 & 26.7 \\
\hline$>10$ & 0 & 0.0 \\
\hline Total & 120 & 100.0 \\
\hline Mean & 2.5 & \\
\hline \multicolumn{3}{|c|}{ Annual Household Income (Naira) } \\
\hline$<200,000$ & 45 & 37.5 \\
\hline $200,000-300,000$ & 49 & 40.8 \\
\hline $300,000-400,000$ & 18 & 15.0 \\
\hline$>400,000$ & 8 & 6.7 \\
\hline Total & 120 & 100 \\
\hline Mean & 252,375 & \\
\hline \multicolumn{3}{|c|}{ Mother's Education } \\
\hline No Formal & 44 & 36.7 \\
\hline Primary & 43 & 35.8 \\
\hline Secondary & 25 & 20.8 \\
\hline Tertiary & 8 & 6.7 \\
\hline Total & 120 & 100.0 \\
\hline \multicolumn{3}{|c|}{ Mother's Access to Resources } \\
\hline Yes & 42 & 35.0 \\
\hline No & 78 & 65.0 \\
\hline Total & 120 & 100.0 \\
\hline \multicolumn{3}{|c|}{ Access to Clean Water } \\
\hline Yes & 49 & 40.8 \\
\hline No & 71 & 59.2 \\
\hline Total & 120 & 100.0 \\
\hline \multicolumn{3}{|c|}{ Access to Sanitation Facilities } \\
\hline Yes & 33 & 27.5 \\
\hline No & 87 & 72.5 \\
\hline Total & 120 & 100.0 \\
\hline
\end{tabular}

Source: Field survey, 2017

Journal of the Faculty of Agriculture and Veterinary Medicine, Imo State University Owerri website: www ajol.info 
Volume 17 Number 2, October 2019 pp 148 - 163

Table 2: Logit Regression Result of Factors Influencing Nutritional Status

\begin{tabular}{lll}
\hline Variables & Coefficient & t-value \\
\hline Child's Sex & $0.615^{*}$ & 1.916 \\
Child's Age & $1.371 * * *$ & 2.892 \\
Household Size & -0.458 & -0.751 \\
Mother's Education & $-0.641^{* * *}$ & -3.470 \\
School Feeding Programme & $-1.084 * * *$ & -2.925 \\
Mother's Access to Resources & 0.571 & 1.463 \\
Access to Clean Water & $-0.315^{* * *}$ & -2.500 \\
Access to Sanitation & $-0.327 * * *$ & -2.692 \\
Household Income & $-0.795^{* *}$ & -2.419 \\
Constant & $-7.195^{* * *}$ & -2.733 \\
\hline
\end{tabular}

Source: Field survey, (2017)

***Significant at $1 \%, * *$ significant at $5 \%, *$ significant at $10 \%$.

Number of observation $=120 ; \operatorname{LR~chi~}^{2}(9)=78.90 ;$ Prob $>\operatorname{chi}^{2}=0.0000$;

Log likelihood $=-83.11093657$ and Pseudo $R^{2}=0.6541$ 
Journal of Agriculture and Food Sciences

Adebisi, O.A., Adebisi L.O., Jonathan A., Ajani O.O. and 163

Volume 17 Number 2, October 2019 pp 148 - 163

Table 3: Chi- Square Test Statistics

\begin{tabular}{lccc}
\hline & Value & Df & Asymp. Sig. (2-sided) \\
\hline Pearson Chi-Square & $37.263^{\mathrm{a}}$ & 1 & 0.000 \\
Likelihood Ratio & 39.034 & 1 & 0.000 \\
$\begin{array}{l}\text { Linear-by-Linear- } \\
\text { Association }\end{array}$ & 2.865 & 1 & 0.018 \\
N of Valid Cases & 120 & & \\
\hline
\end{tabular}

a. 0 cells $(0.0 \%)$ have expected count less than 5 .

The minimum expected count is 22.72

Table 4: Symmetric Measures

\begin{tabular}{llll}
\hline & & Value & Approx. Sig. \\
\hline Nominal by Nominal & Cramer's V & .316 & .000 \\
& & 120 & \\
N of Valid Cases & & \\
a. Not assuming the null hypothesis. \\
b. Using the asymptotic standard error assuming the null hypothesis.
\end{tabular}

Journal of the Faculty of Agriculture and Veterinary Medicine, Imo State University Owerri website: www ajol.info 